\title{
MRI and encephalography in fatal eastern equine encephalitis
}

\section{Figure $\quad$ MRI and EEG findings}

Case 1
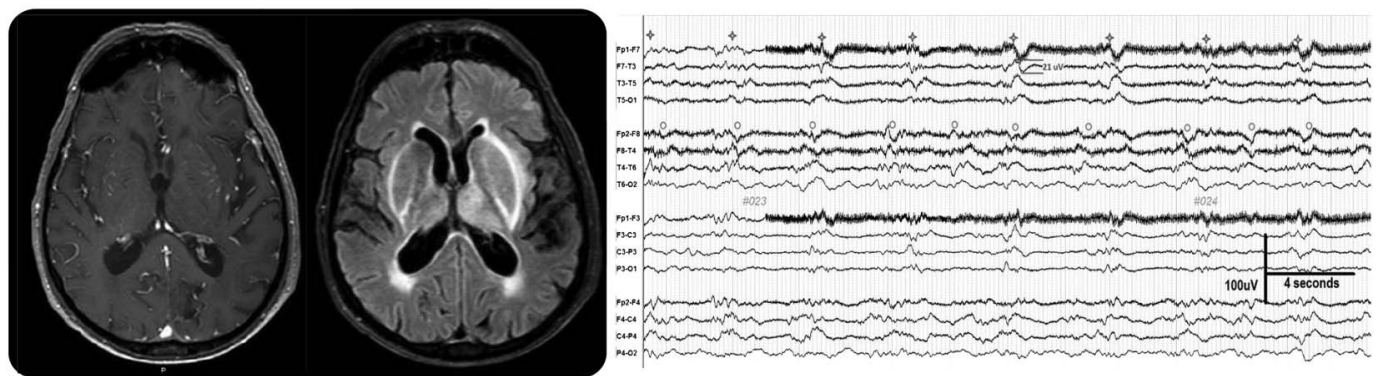

Case 2

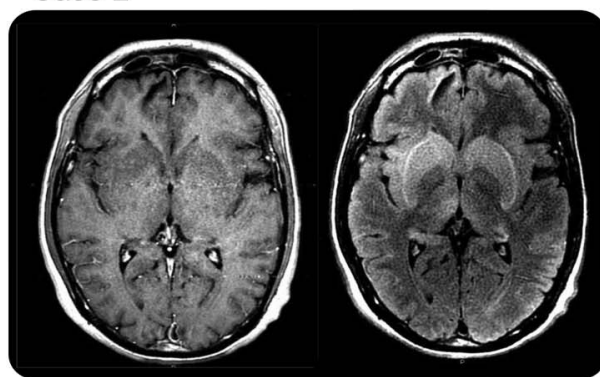

MRI T1 - Gadolinium

T2 FLAIR

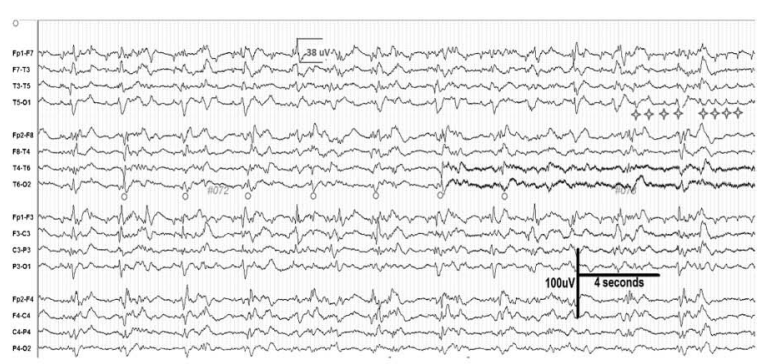

EEG

The 1.5T MRI T2 fluid-attenuated inversion recovery (FLAIR) hyperintense signal in external and internal capsules of both cases (right images) and T1 postgadolinium contrast putaminal enhancement in case 1 only (left image). EEGs with 0.25 - to $0.5-\mathrm{Hz}$ periodic complexes (marked with circles [right] and stars [left] in case 1 and circles [right] in case 2) and temporal periodic lateralized epileptiform discharges (marked with stars [left] in case 2).

Eastern equine encephalitis (EEE) is the most severe of the mosquito-borne encephalitides, with a case fatality rate estimated at $36 \% .{ }^{1}$ We describe 2 fatal cases of seropositive EEE in men. In both patients, EEG monitoring revealed periodic 0.25 - to $0.5-\mathrm{Hz}$ transients with lower voltages $(\sim 20-40 \mu \mathrm{V})$ than typically seen in herpes encephalitis $(\sim 100-500 \mu \mathrm{V})$, and MRI revealed a symmetric pattern of T2 hyperintensity in the lentiform nuclei, as previously noted ${ }^{1,2}$ (figure). Considered together, these MRI and EEG findings suggest a distinctive pattern that may be pathognomonic for EEE in the appropriate clinical context.

Mohamed-Ali Babi, MD, Todd Raleigh, MD, Robert E. Shapiro, MD, PhD, Joseph McSherry, MD, PhD, Angela Applebee, $M D$

From the Department of Neurological Sciences, University of Vermont College of Medicine, Burlington.

Study funding: No targeted funding reported.

Disclosure: Dr. Babi, Dr. Raleigh, Dr. Shapiro, and Dr. McSherry report no disclosures relevant to the manuscript. Dr. Applebee serves on scientific advisory boards for Acorda Therapeutics, Genzyme, and Teva Pharmaceuticals, and is or has been involved in clinical trials sponsored by Novartis, Acorda, Sanofi Aventis, Opexa Therapeutics, Genentech/Roche, Biogen, Teva Pharmaceuticals, and Serono. Go to Neurology.org for full disclosures.

Correspondence to Dr. Babi: Mohamed-Ali.Babi@vtmednet.org

1. Deresiewicz RL, Thaler SJ, Hsu L, Zamani AA. Clinical and neuroradiographic manifestations of eastern equine encephalitis. N Engl J Med 1997;336:1867.

2. Ketai L, Alrahji AA, Hart B, Enria D, Mettler F Jr. Radiologic manifestations of potential bioterrorist agents of infection. AJR Am J Roentgenol 2003;180:565-575. 


\section{Neurology}

\section{MRI and encephalography in fatal eastern equine encephalitis}

Mohamed-Ali Babi, Todd Raleigh, Robert E. Shapiro, et al. Neurology 2014;83;1483

DOI 10.1212/WNL.0000000000000876

\section{This information is current as of October 13, 2014}

\section{Updated Information \&} Services

\section{References}

Subspecialty Collections

Permissions \& Licensing

\section{Reprints}

including high resolution figures, can be found at: http://n.neurology.org/content/83/16/1483.full

This article cites 2 articles, 0 of which you can access for free at: http://n.neurology.org/content/83/16/1483.full\#ref-list-1

This article, along with others on similar topics, appears in the following collection(s):

All Infections

http://n.neurology.org/cgi/collection/all_infections EEG

http://n.neurology.org/cgi/collection/eeg

Encephalitis

http://n.neurology.org/cgi/collection/encephalitis

MRI

http://n.neurology.org/cgi/collection/mri

Information about reproducing this article in parts (figures,tables) or in its entirety can be found online at:

http://www.neurology.org/about/about_the_journal\#permissions

Information about ordering reprints can be found online:

http://n.neurology.org/subscribers/advertise

Neurology ${ }^{\circledR}$ is the official journal of the American Academy of Neurology. Published continuously since 1951, it is now a weekly with 48 issues per year. Copyright () 2014 American Academy of Neurology. All rights reserved. Print ISSN: 0028-3878. Online ISSN: 1526-632X.

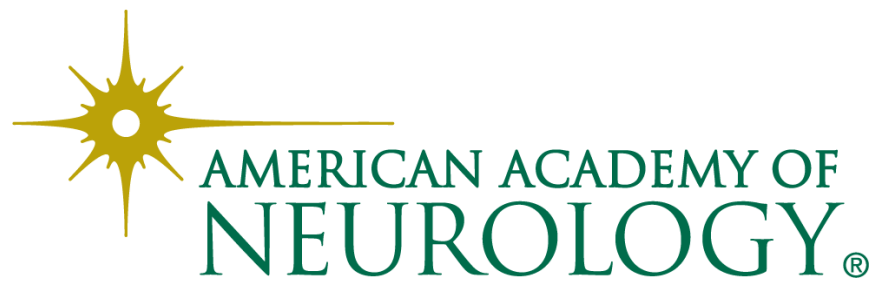

